\title{
Retention and development of eggs transferred to the uterus at various times after ovulation in the rabbit
}

\author{
C. E. Adams \\ A.R.C. Institute of Animal Physiology, Animal Research Station, 307 Huntingdon Road, \\ Cambridge CB3 OJQ, U.K.
}

\begin{abstract}
Summary. The pattern of egg expulsion/retention was determined in rabbits $24 \mathrm{~h}$ after transfer of eggs to the uterus $24-84 \mathrm{~h} \mathrm{p.c.} \mathrm{Nearly} \mathrm{all} \mathrm{eggs} \mathrm{transferred} \mathrm{at} 24$ or $36 \mathrm{~h}$ p.c. were expelled into the vagina but from $36 \mathrm{~h}$ onwards an increasing proportion was retained in utero, although maximum retention was not recorded until 76-84 h p.c.

In rabbits in which both uterine horns were ligated before egg transfer at $12-48 \mathrm{~h}$ p.c., egg development was evaluated 24 or $72 \mathrm{~h}$ later, or at term. Practically all eggs transferred at 12 or $24 \mathrm{~h}$ perished within 3 days; however, from transfers at $36 \mathrm{~h}$ $25 \%$ of eggs implanted with $40 \%$ survival to term, and further improvement in endometrial receptivity occurred by $48 \mathrm{~h}$. These findings reveal a clear time difference between limitations imposed by endometrial and myometrial function on egg development.

Limited attempts to create more favourable uterine conditions by means of progesterone treatment were unsuccessful.
\end{abstract}

\section{Introduction}

In the rabbit the eggs normally enter the uterus 72-84 h after mating (Cruikshank, 1797; Assheton, 1894; Gregory, 1930; Hodgson \& Pauerstein, 1976); neither premature nor belated entry of eggs into the uterus is common (Adams, 1960a, 1965; and unpublished observations) and 'on time' entry is a prerequisite for survival, as the following observations show. If entry is delayed experimentally, e.g. by tubal ligation, rabbit eggs fail to develop beyond the 84-90 h, early blastocyst stage (Adams, 1958) and nearly all are non-viable by $108 \mathrm{~h}$ (Adams, 1973). On the other hand, eggs placed prematurely in the early (Day 1) progestational uterus fail to survive, because they are expelled or degenerate in situ, and even at $48 \mathrm{~h}$ only about $25 \%$ survive (Chang, 1950), with most of the loss occurring before implantation (Adams, 1979). Proof of expulsion was obtained by recovering eggs from the vagina (Noyes, Adams \& Walton, 1959), and the influence of progesterone was clearly demonstrated both by reducing the numbers of corpora lutea and treatment with exogenous progesterone (Adams, 1965).

The purpose of the present investigation was (1) to evaluate the retention/expulsion of eggs relative to time elapsing from ovulation, and (2) to determine the fate of eggs transferred prematurely and then held in utero by ligation. Egg development was also investigated in rabbits treated with exogenous progesterone in an attempt to suppress myometrial activity. A brief account of part of this work has been presented elsewhere (Adams, 1979). 


\section{Materials and Methods}

A total of 140 young, parous rabbits, weighing $3-4 \mathrm{~kg}$, from our own colony, was used. They were kept in individual cages and allowed free access to a pelleted diet (Diet 18, E. Dixon \& Sons, Ware, Herts) and water. From September to May artificial lighting was in use between $06: 00$ and $20: 00 \mathrm{~h}$.

A series of experiments was carried out, involving 43 recipients and 9 donors (Exp. 1), 50 recipients and 9 donors (Exp. 2) and 21 recipients and 8 donors (Exp. 3).

\section{Donors}

In 6 of the 26 donors superovulation was induced by treatment with a horse anterior pituitary preparation, HP1, as described elsewhere (Adams, 1971). At $15 \mathrm{~h}$ after the final priming injections 30 i.u. hCG (Gonadotrophon: Paines \& Byrne Ltd, Greenford, Middlesex) were injected i.v. immediately after mating. All donors were mated with 2 fertile males.

Eggs were recovered from the oviducts by flushing each with $2 \mathrm{ml}$ phosphate-buffered saline, pH 7.4 (Dulbecco 'A': Oxoid Ltd, London) either at autopsy at $40 \mathrm{~h}$ p.c. (Exp. 1) or at $36 \mathrm{~h}$ p.c. (Exp. 3) or in vivo at 24-48 h p.c. (Exp. 2).

\section{Recipients}

These animals were either mated with 2 fertile males and/or given 30 i.u. hCG to induce ovulation. A total of 13 does (Exp. 3) was treated with progesterone (Organon Laboratories Ltd, Morden, Surrey), each doe receiving $2 \mathrm{mg}$ in $0.2 \mathrm{ml}$ arachis oil s.c. at 12 and $24 \mathrm{~h}$ after hCG. At fixed intervals after hCG treatment, i.e. 24-84 h (Exp. 1), 12-48 h (Exp. 2) or 36-60 h (Exp. 3), laparotomy was performed, using pentobarbitone sodium (Sagatal: May \& Baker Ltd, Dagenham, Essex) and halothane (Fluothane: I.C.I. Ltd, Macclesfield, Cheshire) delivered in oxygen : nitrous oxide (1:1) (Entonox, British Oxygen Company, Brentford, Middlesex) via a face mask to induce anaesthesia.

In 70 of the recipients (15 in Exp. 1, 42 in Exp. 2 and 13 in Exp. 3) both oviducts were flushed in vivo to provide eggs for auto-transfer. If the number of eggs recovered was lower than the number of corpora lutea the corresponding oviduct was ligated near the utero-tubal junction in order to prevent any remaining eggs from entering the uterus. Except for 12-h recipients (Exp. 2 ), which received 24-h eggs, the remaining transfers were synchronous.

In Exp. 1, the vagina was ligated with No. 3 Arbrasilk (Armour Pharmaceuticals, Eastbourne, Sussex) before transferring eggs to each uterine horn, essentially as described elsewhere (Adams, 1962). In Exp. 2 each uterine horn was ligated with Arbrasilk within $1 \mathrm{~cm}$ of the cervix, and in Exp. 3 one horn was similarly ligated in 9 does receiving eggs $36 \mathrm{~h}$ p.c.

\section{Further procedures}

Experiment 1. At $24 \mathrm{~h}$ after egg transfer recipients were killed by the rapid injection i.v. of $1.5 \mathrm{ml}$ pentobarbitone sodium (Expiral: Abbott Laboratories, Queenborough, Kent) and then exsanguinated by severing the jugular veins. The whole genital tract was removed and placed on absorbent paper; excess fat and connective tissue were trimmed away from the vagina, uterine horns and oviducts, which were then separated. The vagina was held over a $10 \mathrm{~cm}$ watchglass and, after cutting the ligature, sometimes with the escape of fluid, it was flushed twice with saline $(0.9 \%(\mathrm{w} / \mathrm{v}) \mathrm{NaCl})$, using a 21 -gauge $\times 27 \mathrm{~mm}$ hypodermic needle and a $10 \mathrm{ml}$ syringe. The uterine horns were then separated from the vaginal remnant before flushing each one with $10 \mathrm{ml}$ saline at least twice in opposite directions. Each oviduct was flushed with $2 \mathrm{ml}$ saline. The flushings were searched for eggs whose stage of development and condition were noted. 
Experiment 2. At 24 or $72 \mathrm{~h}$ after transfer 28 recipients were killed. The ligatures were removed before flushing the uteri, as described above. In the remaining 22 does the ligatures were removed at laparotomy 3-8 days after egg transfer. When this took place after implantation (17 cases) the conceptuses were counted and measured (Adams, 1960b). These does were allowed to go to term when the litter size was recorded.

Experiment 3. Four recipients at $36 \mathrm{~h}$ and 5 at $60 \mathrm{~h}$ were autopsied on Days $4 \frac{1}{2}$ and $5 \frac{1}{2}$ respectively. The uteri were flushed and the flushings examined for eggs. A further $360-\mathrm{h}$

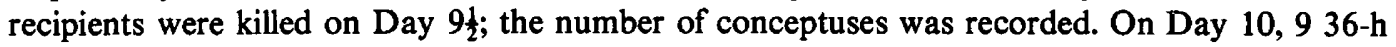
recipients were subjected to laparotomy and the number of conceptuses was noted; pregnant does were kept to term.

\section{Results}

\section{Experiment 1}

As shown in Table 1, 390 eggs, equivalent to $87 \%$ of the total transferred, were recovered from the 43 recipients. Following transfer at 24 or $36 \mathrm{~h}$ after hCG, nearly all of the eggs were recovered from the vagina. As the interval from hCG to transfer lengthened, the proportion of eggs retained in utero increased, most sharply between 48 and $54 \mathrm{~h}$, eventually reaching maximal levels by $76-84 \mathrm{~h}$.

Table 1. Egg recovery from the uterus and vagina $24 \mathrm{~h}$ after uterine transfer to rabbits treated with hCG $24-84 \mathrm{~h}$ previously

\begin{tabular}{|c|c|c|c|c|}
\hline \multirow{2}{*}{$\begin{array}{l}\text { Time between hCG and } \\
\text { egg transfer (h) }\end{array}$} & \multirow{2}{*}{$\begin{array}{l}\text { No. of } \\
\text { rabbits }\end{array}$} & \multirow{2}{*}{$\begin{array}{l}\text { No. of eggs recovered/ } \\
\text { no. transferred } \\
\text { (\%) }\end{array}$} & \multicolumn{2}{|c|}{ No. of eggs recovered (\%) from } \\
\hline & & & Uterus & Vagina \\
\hline 24 & 5 & $48 / 59(81.4)$ & $1(2 \cdot 1)$ & $47(97.9)$ \\
\hline 36 & 5 & $37 / 42(88 \cdot 1)$ & $2(5.4)$ & $35(94.6)$ \\
\hline 42 & 3 & $29 / 35(82.9)$ & $11(37.9)$ & $18(62 \cdot 1)$ \\
\hline 48 & 5 & $36 / 39(92.3)$ & $11(30.6)$ & $25(69.4)$ \\
\hline 54 & 3 & $35 / 41(85.4)$ & $26(74 \cdot 3)$ & $9(25 \cdot 7)$ \\
\hline 60 & 5 & $24 / 26(92 \cdot 3)$ & $20(83 \cdot 3)$ & $4(16 \cdot 7)$ \\
\hline 68 & 4 & $22 / 29(75.9)$ & $19(86 \cdot 4)$ & $3(13 \cdot 6)$ \\
\hline 72 & 4 & $45 / 48(93.8)$ & $40(88.9)$ & $5(11 \cdot 1)$ \\
\hline 76 & 3 & $54 / 60(90.0)$ & $52(96 \cdot 3)$ & $2(3 \cdot 7)$ \\
\hline 80 & 4 & $40 / 49(81 \cdot 6)$ & $38(95.0)$ & $2(5.0)$ \\
\hline 84 & 2 & $20 / 22(90.9)$ & $19(95 \cdot 0)$ & $1(5 \cdot 0)$ \\
\hline
\end{tabular}

For 28 recipients it was possible to distinguish between transferred (fertilized) and native (unfertilized) eggs, $87 \%(272 / 313)$ of which were recovered (Table 2). In recipients operated on at 24 or $36 \mathrm{~h}$ after hCG, many of the native eggs were found in the vagina, but when the operation was carried out later, especially from $60 \mathrm{~h}$ onwards, $99 \%(177 / 178)$ of the eggs were found in the uterus. In does examined after $66 \mathrm{~h}$ p.c. no native eggs were found in the oviducts.

\section{Experiment 2}

Following transfers to the ligated uterus at $12 \mathrm{~h}$ relatively few eggs could be recovered $24 \mathrm{~h}$ later and no egg apparently survived to $72 \mathrm{~h}$. There was an improvement in uterine receptivity, particularly between 24 and $36 \mathrm{~h}$ p.c. By $48 \mathrm{~h}$ p.c. the uterus appeared capable of sustaining the majority of eggs transferred.

Details of the stage of development and condition of the eggs recovered are presented in Table 3 and examples of some of the eggs are shown in Plates 1 and 2. Eggs transferred at $24 \mathrm{~h}$ 
Table 2. Site of recovery of native eggs $24 \mathrm{~h}$ after a laparotomy and transfer of alien eggs which took place $24-48 \mathrm{~h}$ after hCG treatment

\begin{tabular}{ccccccc}
\hline & & & \multicolumn{4}{c}{ No. of eggs recovered } \\
\cline { 5 - 7 } $\begin{array}{c}\text { Time between hCG and } \\
\text { laparotomy (h) }\end{array}$ & $\begin{array}{c}\text { No. of } \\
\text { does }\end{array}$ & $\begin{array}{c}\text { No. of } \\
\text { ovulations }\end{array}$ & Total (\%) & Oviducts & Uteri & Vagina \\
\hline 24 & 2 & 18 & $12(66)$ & 0 & 0 & 12 \\
36 & 2 & 25 & $22(88)$ & 9 & 0 & 13 \\
42 & 3 & 33 & $32(97)$ & 10 & 18 & 4 \\
54 & 3 & 37 & $32(86)$ & 0 & 30 & 2 \\
60 & 1 & 10 & $10(100)$ & 0 & 10 & 0 \\
68 & 4 & 55 & $50(91)$ & 0 & 49 & 1 \\
72 & 4 & 39 & $35(90)$ & 0 & 35 & 0 \\
76 & 3 & 35 & $30(86)$ & 0 & 30 & 0 \\
80 & 4 & 41 & $33(80)$ & 0 & 33 & 0 \\
84 & 2 & 20 & $20(100)$ & 0 & 20 & 0 \\
\hline
\end{tabular}

p.c. to 12 - and 24-h recipients underwent cleavage, but the majority appeared abnormal, displaying 'pale' blastomeres ( $\mathrm{Pl}$. 1, Fig. 1), and/or degenerate, with the blastomeres disintegrating and lacking the characteristic organization of the early morula (Pl. 1, Fig. 2). From 2 recipients 4 empty zonas were recovered, providing evidence of the disintegration of eggs after disruption of the zona pellucida (Pl. 1, Fig. 3). Nevertheless, 4 of the eggs transferred to a 24-h recipient did develop into blastocysts. Eggs transferred to 36-h recipients cleaved once or twice in $24 \mathrm{~h}$ and by $72 \mathrm{~h}$ several had developed into blastocysts, although the proportion of normal forms was relatively low; examples of abnormal 'blastocysts' either lacking or having an

Table 3. Egg recovery 24 or $72 \mathrm{~h}$ after synchronous transfer to the ligated uterus in the rabbit

\begin{tabular}{|c|c|c|c|c|c|c|}
\hline \multicolumn{2}{|c|}{ Time between } & \multirow{2}{*}{\multicolumn{4}{|c|}{ No. of eggs }} & \multirow[b]{3}{*}{ Condition of eggs } \\
\hline \multirow{2}{*}{$\begin{array}{l}\text { Mating and } \\
\text { egg transfer } \\
\text { (h) }\end{array}$} & \multirow{2}{*}{$\begin{array}{l}\text { Egg transfer } \\
\text { and autopsy } \\
\text { (h) }\end{array}$} & & & & & \\
\hline & & $\begin{array}{l}\text { No. of } \\
\text { does }\end{array}$ & Transferred & $\begin{array}{l}\text { Recovered } \\
(\%)\end{array}$ & $\begin{array}{l}\text { Uterine horns } \\
\text { yielding eggs }\end{array}$ & \\
\hline \multirow[t]{2}{*}{12} & 24 & 4 & 40 & $12(30)$ & $4 / 8$ & $9 \mathrm{M} ; 31-4$ cells \\
\hline & 72 & 1 & 13 & $0(0)$ & $0 / 2$ & \\
\hline \multirow[t]{2}{*}{24} & 24 & 5 & 42 & $23^{*}(55)$ & $7 / 10$ & $\begin{array}{l}19 \mathrm{M} \text {; several degenerate and } 4 \\
\text { empty zonas }\end{array}$ \\
\hline & 72 & 4 & 29 & $5(17)$ & $4 / 8$ & $1 \mathrm{M} ; 3 \mathrm{~B} ; 1$ zona free 'B' \\
\hline \multirow[t]{2}{*}{36} & 24 & 4 & 31 & $22(71)$ & $8 / 8$ & $22 \mathrm{M}$ \\
\hline & 72 & 4 & 36 & $20(56)$ & $7 / 8$ & $\begin{array}{l}7 \mathrm{~B} ; 3 \text { degenerate } \mathrm{B} ; 3 \text { abnormal } \\
\text { B; } 7 \text { zona free ' } \mathrm{B} \text { ' }\end{array}$ \\
\hline \multirow[t]{2}{*}{48} & 24 & 3 & 24 & $21(87)$ & $6 / 6$ & $20 \mathrm{LM} / \mathrm{EB} ; 1 \mathrm{M}$ \\
\hline & 72 & 3 & 31 & $26(84)$ & $6 / 6$ & $26 \mathrm{~B}$ \\
\hline
\end{tabular}

$M=$ morula (8-32 cells); LM = late morula; $\mathrm{EB}=$ early blastocyst; $\mathrm{B}$ = blastocyst.

* Including 4 empty zonas.

Table 4. Outcome of pregnancy following synchronous transfer of fertilized eggs to the ligated uterus in the rabbit and removal of the ligatures immediately before or after implantation

\begin{tabular}{cccccc}
\hline $\begin{array}{c}\text { Time between } \\
\text { mating and egg } \\
\text { transfer }(\mathrm{h})\end{array}$ & $\begin{array}{c}\text { No. of } \\
\text { does }\end{array}$ & $\begin{array}{c}\text { No. of eggs } \\
\text { transferred }\end{array}$ & $\begin{array}{c}\text { No. of } \\
\text { implantations (\%) }\end{array}$ & $\begin{array}{c}\text { No. of does } \\
\text { littering }\end{array}$ & $\begin{array}{c}\text { No. young } \\
\text { born/no. } \\
\text { implantations (\%) }\end{array}$ \\
\hline 36 & 8 & 81 & $19(23)$ & 4 & $8(42)$ \\
42 & 5 & 50 & $26(52)$ & 4 & $14(54)$ \\
48 & 4 & 32 & $21(66)$ & 4 & $16(76)$ \\
& 5 & 36 & - & 5 & 21 \\
\hline
\end{tabular}


PLATE $\cdot 1$
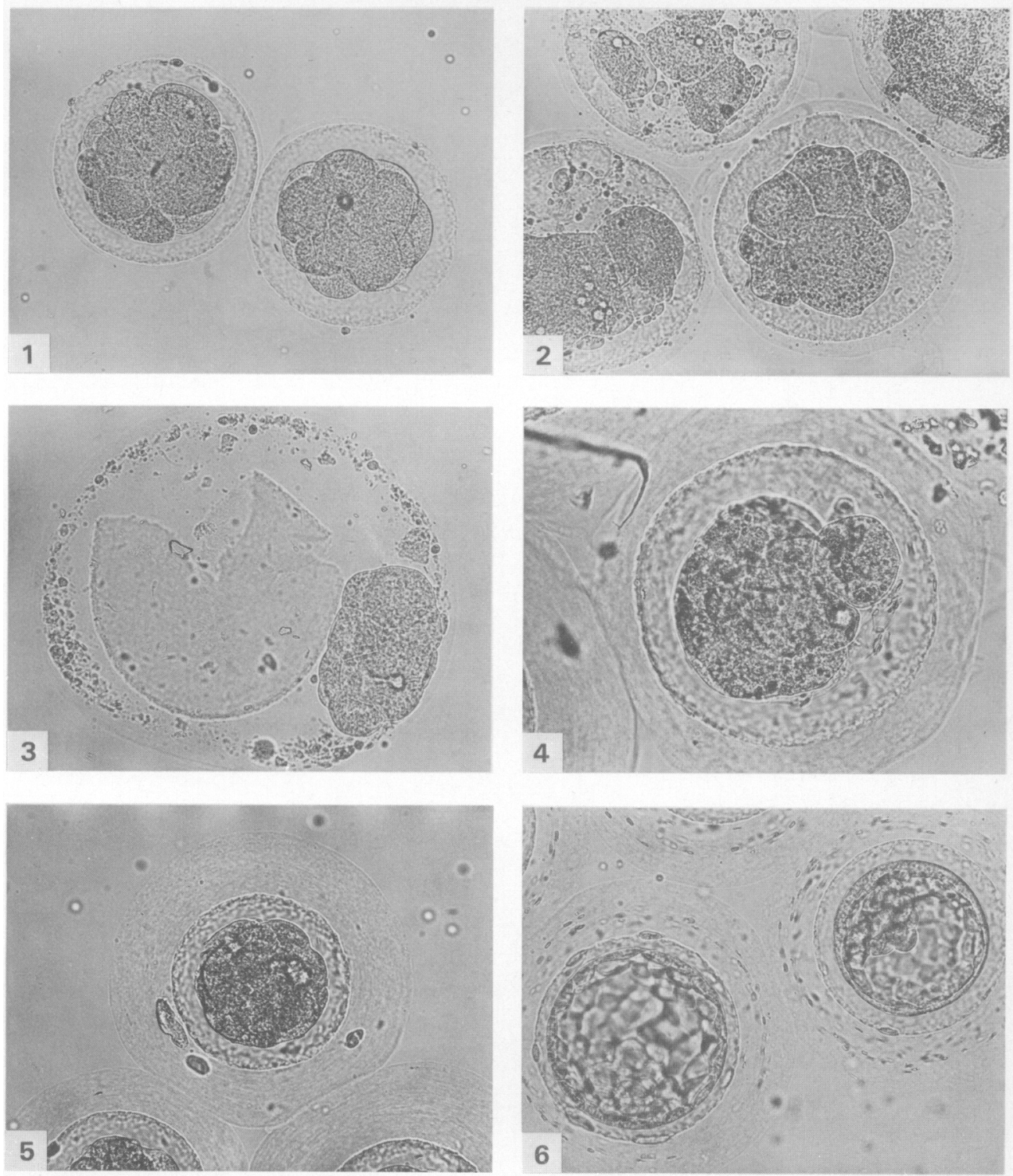

Rabbit eggs were recovered $24 \mathrm{~h}$ after transfer.

Fig. 1. Two 24-h eggs transferred to a 12-h uterus. Although cleavage has taken place the blastomeres appear abnormal and the zona pellucida shows signs of damage. Note the thin mucin layer. $\times 140$.

Fig. 2. Several 24-h eggs transferred to a 24 -h uterus. Note the damaged zona pellucidas and disintegration of blastomeres. $\times 140$.

Fig. 3. A 24-h egg transferred to a 24-h uterus. The zona pellucida has ruptured, liberating the blastomeres which lie within the mucin layer. $\times 140$.

Fig. 4. A 24-h rabbit egg transferred to a 24-h uterus. $\times 225$.

Fig. 5. A 36 -h rabbit egg transferred to a 36 -h uterus. Cleavage has occurred and the egg appears normal. $\times 140$.

Fig. 6. Two 48-h rabbit eggs transferred to a 48-h uterus. Blastulation and expansion are occurring and the zona pellucida is thinning; normabappeatanceonx 140 cientifica.com at $04 / 26 / 2023$ 10:54:13AM 

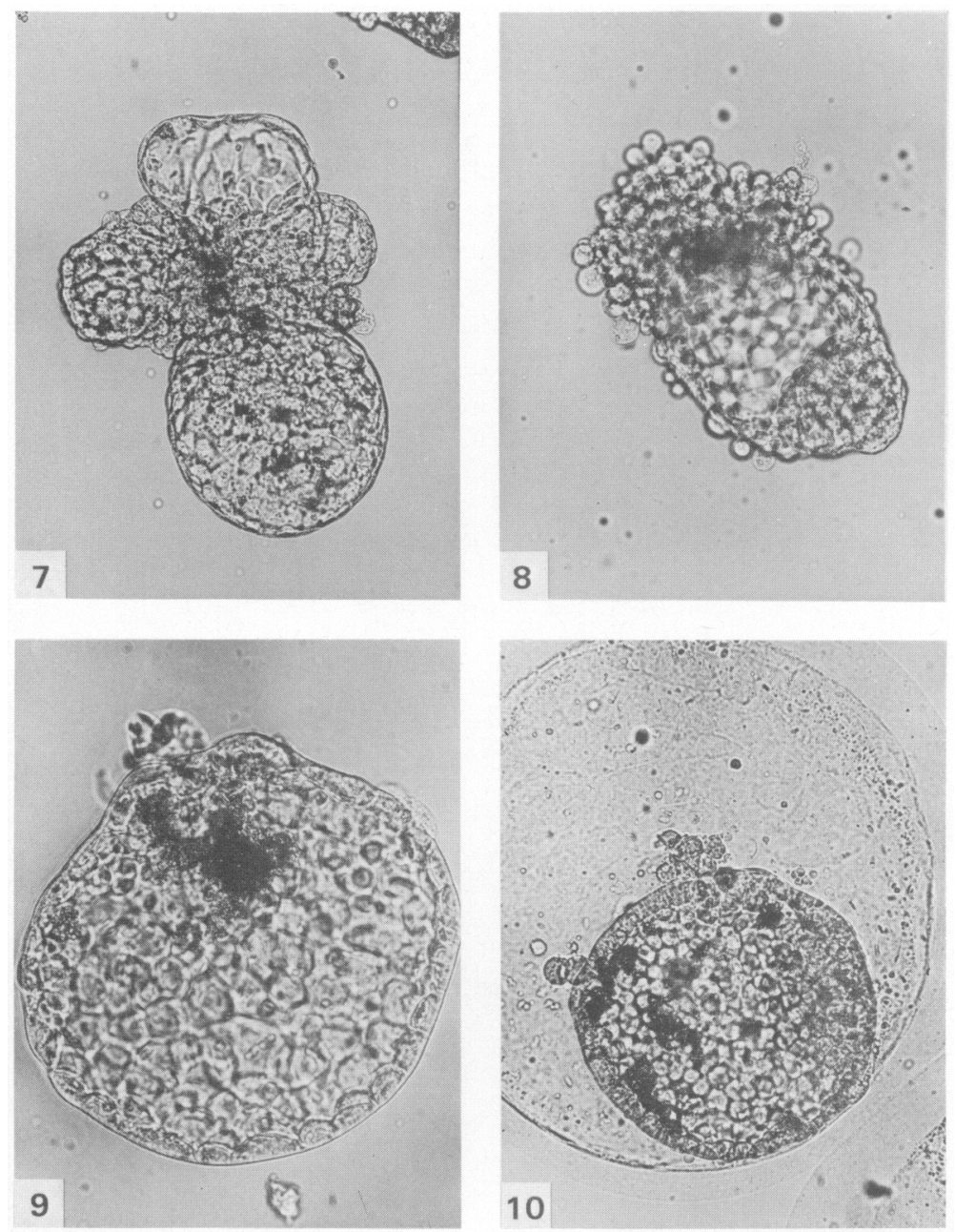

Figs 7-10. 36-h rabbit eggs transferred to $36-\mathrm{h}$ uteri and recovered $72 \mathrm{~h}$ later. Note the various atypical forms of 'blastocysts', including 3 which lack the zona pellucida (Figs 7, 8 and 9). In Fig. 10 the zona pellucida, surrounded by a mucin layer, is still present but very abnormal. Figs 7,8 and 10, $\times 140$; Fig. 9, $\times 280$. 
abnormal zona pellucida are shown in Pl. 2. Figs 7-10. Eggs transferred at $48 \mathrm{~h}$ developed on time into blastocysts.

When does were allowed to go to term nearly $25 \%$ of the eggs transferred at $36 \mathrm{~h}$ succeeded in implanting and nearly half of those implanting survived to term (Table 4). The yield of implantations and of young born increased markedly as the time of transfer was advanced to $48 \mathrm{~h}$, reflecting a rapid improvement in uterine conditions.

\section{Experiment 3}

The results presented in Table 5 show that the majority of the eggs in the 36-h recipients were lost within 3 days of transfer. Further, the proportions of eggs implanting in ligated and in non-ligated uteri were remarkably similar (10.4 and $10.3 \%$, respectively), suggesting that the loss was not due to expulsion but rather to destruction in utero.

Table 5. Outcome of transferring $36-\mathrm{h}$ eggs to $36-\mathrm{h}$ progesterone-treated or to 60 -h recipient rabbits

\begin{tabular}{|c|c|c|c|c|c|c|c|}
\hline \multicolumn{2}{|c|}{ Time between } & \multirow[b]{3}{*}{$\begin{array}{l}\text { No. of } \\
\text { does }\end{array}$} & \multirow{2}{*}{\multicolumn{2}{|c|}{ No. of eggs }} & \multirow{3}{*}{$\begin{array}{c}\text { No. of } \\
\text { implantations } \\
\text { (\%) }\end{array}$} & \multirow{3}{*}{$\begin{array}{l}\text { No. of } \\
\text { does } \\
\text { littering }\end{array}$} & \multirow{3}{*}{$\begin{array}{l}\text { No. of } \\
\text { young } \\
\text { born }\end{array}$} \\
\hline \multirow{2}{*}{$\begin{array}{l}\text { Mating and } \\
\text { egg transfer } \\
\text { (h) }\end{array}$} & \multirow{2}{*}{$\begin{array}{l}\text { Egg transfer } \\
\text { and autopsy } \\
\text { (h) }\end{array}$} & & & & & & \\
\hline & & & Transferred & $\begin{array}{c}\text { Recovered } \\
(\%)\end{array}$ & & & \\
\hline 36 & 72 & 4 & 43 & $2(5)$ & - & - & - \\
\hline 36 & - & 9 & $\begin{array}{l}29^{*} \\
67\end{array}$ & - & $\begin{array}{l}3(10) \\
7(10)\end{array}$ & 1 & 2 \\
\hline 60 & 72 & 5 & 50 & $29(58)$ & 一 & - & - \\
\hline 60 & 168 & 3 & 15 & - & $7(47)$ & - & - \\
\hline
\end{tabular}

* Uterine horns ligated.

In 60-h recipients more than half of the eggs transferred were accounted for at autopsy 3 days after transfer. Apart from 22 normal blastocysts, there were 3 degenerate blastocysts, 1 very small blastocyst and 3 degenerate morulae. In 2 out of 3 similar recipients, autopsied on Day $9 \frac{1}{2}$, there were 7 normal implantations (47\%); 2 small degenerate blastocysts were recovered from the other doe.

\section{Discussion}

The present study provides a comprehensive picture of the pattern of egg expulsion/retention by the rabbit uterus relative to time elapsing from ovulation. There are two points of special interest: (1) the very close agreement between the time the eggs normally enter the uterus, $78-84 \mathrm{~h}$ p.c. (Hodgson \& Pauerstein, 1976), and the near-total suppression of the expulsion mechanism (see Table 1), and (2) the clear divergence between limitations imposed by endometrial and myometrial function, as is evident from a comparison of the findings shown in Tables 1 and 3 . For example, whereas the majority of eggs transferred to the 36-h uterus are expelled into the vagina, development to term is possible if expulsion is prevented by uterine ligation. It therefore appears that endometrial 'receptivity' evolves at a faster rate than myometrial activity abates, presumably reflecting the known greater sensitivity or faster response of the endometrium to progesterone. Although half of one corpus luteum can induce maximal endometrial proliferation (Brouha, 1934), nearly the full complement of corpora lutea is required to prevent expulsion of eggs (Adams, 1965). Attention has been drawn already to the possible clinical significance of this finding (Adams, 1969).

Eggs transferred to and retained in the uteri of oestrous does are known to undergo 
degeneration, including loss of the zona pellucida (Chang, 1955; Adams, 1969). The present findings indicate that conditions within the uterus may remain unfavourable until at least $36 \mathrm{~h}$ p.c. in some does. Although some eggs transferred at that time did develop normally, others underwent cleavage and blastulation only to give rise to abnormal forms, probably as a result of malfunction and/or loss of the zona pellucida. This observation provides further evidence of the need for the zona pellucida, and is indicative of the key role of the zona in the evolution of the rabbit blastocyst which, in its absence or malfunction, becomes disorganized, as may also happen in culture in vitro (Adams, 1970). In the rabbit the zona pellucida normally exists up to implantation.

In rabbits having eggs transferred to the uterus, the subsequent finding of native eggs in the vagina at autopsy when they should have been in the oviducts was most unexpected. For the time being, no explanation can be offered except to note that the phenomenon was time dependent, being most evident in does treated at $24 \mathrm{~h}$ p.c., still operative at $36 \mathrm{~h}$ but then declining sharply by $42 \mathrm{~h}$. A similar condition has also been observed following egg transfer to the rabbit oviduct (C. E. Adams, unpublished observations). Accelerated tubal transport of native fertilized eggs occurred in mares to which rabbit eggs has been transferred into the uterus through the cervix (Oguri \& Tsutsumi, 1972).

In $36-\mathrm{h}$ recipients treatment with progesterone at 12 and $24 \mathrm{~h}$ failed to elicit the conditions obtaining in 60-h recipients, when judged on the basis of egg recovery or development. Available evidence points to the 'loss' of eggs in utero rather than to their expulsion. It appears as if the treatment could have been successful in suppressing myometrial activity, thereby permitting retention of eggs, yet failing due to the creation of a too advanced endometrium, which can lead to egg degeneration (Adams, 1971). This aspect poses problems which will require further investigation and their successful solution could facilitate the further development of non-surgical egg transfer procedures in species other than the rabbit. In that way transfers could be carried out nearer the time of ovulation, using less developed eggs; such an approach could be advantageous for work with human and bovine subjects, e.g. to shorten the time eggs might spend in culture after fertilization in vitro.

I thank Miss Wendy Hutchings for technical assistance.

\section{References}

Adams, C.E. (1958) Egg development in the rabbit: the influence of post coital ligation of the uterine tube and of ovariectomy. J. Endocr. 16, 283-293.

Adams, C.E. (1960a) Early embryonic mortality in the rabbit. J. Reprod. Fert. 3, 315-316.

Adams, C.E. (1960b) Studies on prenatal mortality in the rabbit, Oryctolagus cuniculus: the amount and distribution of loss before and after implantation. $J$. Endocr. 19, 325-344.

Adams, C.E. (1962) Studies on prenatal mortality in the rabbit, Oryctolagus cuniculus: the effect of transferring varying numbers of eggs. $J$. Endocr. 24, 471-490.

Adams, C.E. (1965) Influence of the number of corpora lutea on endometrial proliferation and embryo development in the rabbit. $J$. Endocr. 31, xxix-xxx, Abstr.

Adams, C.E. (1969) Egg-uterus interrelationships. In Advances in the Biosciences, vol. 4, pp. 149-162. Ed. G. Raspé. Pergamon Press, Oxford.

Adams, C.E. (1970) The development of rabbit eggs after culture in vitro for 1-4 days. J. Embryol. exp. Morph. 23, 21-24.
Adams, C.E. (1971) The fate of fertilized eggs transferred to the uterus or oviduct during advancing pseudopregnancy in the rabbit. J. Reprod. Fert. 26, 99-111.

Adams, C.E. (1973) The development of rabbit eggs in the ligated oviduct and their viability after re-transfer to recipient rabbits. J. Embryol. exp. Morph. 29, 133-144.

Adams, C.E. (1979) Consequencies of accelerated ovum transport, including a re-evaluation of Estes' operation. J. Reprod. Fert. 55, 239-246.

Assheton, R. (1894) A re-investigation into the early stages of the development of the rabbit. J. microsc. Sci. 37, 113-164.

Brouha, A. (1934) Étude des rapports entre les modifications pré-gravidiques de la maqueuse utérine et les hormones ovariennes. Archs Biol., Liège 45, 571-609.

Chang, M.C. (1950) Development and fate of transferred rabbit ova or blastocyst in relation to the ovulation time of recipients. J. exp. Zool. 114, 197-226.

Chang, M.C. (1955) Développement de la capacité fertilisatrice des spermatozoïdes du lapin à l'intérieur 
du tractus génital femelle et fécondabilité des oeufs de lapin. In La Fonction Tubaire, pp. 40-52. Masson, Paris.

Cruikshank, W. (1797) Experiments in which, on the third day after impregnation, the ova of rabbits were found in the fallopian tubes; and on the fourth day after impregnation in the uterus itself; with the first appearance of the foetus. Phil. Trans. R. Soc. Lond. 87, 197-214.

Gregory, P.W. (1930) The early embryology of the rabbit. Contrib. Embryol. Carneg. Instn 21, 141168.
Hodgson, B.J. \& Pauerstein, C.J. (1976) Comparison of oviductal transport of fertilized and unfertilized ova after HCG or coitus induced ovulation in rabbits. Biol. Reprod. 14, 377-380.

Noyes, R.W., Adams, C.E. Walton, A. (1959) The transport of ova in relation to the dosage of oestrogen in ovariectomized rabbits. J. Endocr. 18, 108-117.

Oguri, N. \& Tsutsumi, Y. (1972) Non-surgical recovery of equine eggs, and an attempt at non-surgical egg transfer in horses. J. Reprod. Fert. 31, 187-195.

Received 7 January 1980 